\title{
PAPER
}

Cite this: DOI: $10.1039 / \times 0 \times x 00000 x$

\section{Iridium(I) hydroxides in catalysis: rearrangement of allylic alcohols to ketones}

Received 00th January 2012

Accepted 00th January 2012

\author{
David J. Nelson, ${ }^{\text {a,b }}$ José A. Fernández-Salas, ${ }^{a}$ Byron J. Truscott ${ }^{\mathrm{a}}$ and Steven P.
} Nolan $^{\mathrm{a}} *$

DOI: $10.1039 / \times 0 \times x 00000 x$

www.rsc.org/

The iridium(I) hydroxide complex $\left[\operatorname{Ir}(\mathrm{OH})(\mathrm{COD})\left(\mathrm{I}^{i} \mathrm{Pr}\right)\right]$ has been shown to be a competent catalyst for the rearrangement of allylic alcohols to ketones. Reactions proceed in short reaction times $(1-1.5 \mathrm{~h})$ with microwave heating, in the absence of additives.

Isomerisation reactions are, by their very nature, atom-efficient transformations, and allow for the interconversion of useful functional groups. Allylic alcohol rearrangements to form ketones comprise one such type of isomerisation reaction (Scheme 1). Allylic alcohol isomerisation can be catalysed by a variety of metal systems, ${ }^{1}$ including iridium, ${ }^{2,3}$ although we have recently reported a highly-active ruthenium system for this transformation. ${ }^{4}$ With the appropriate ligand sphere, asymmetric variants are also possible, albeit with high loadings of expensive catalyst complexes ( $c a .5$ mol\%). ${ }^{5}$ Many iridium-catalysed methodologies require the use of dihydrogen in order to generate the active iridium(III) dihydride species in $s i t u{ }^{6-8}$ the reaction solution must then be degassed to remove excess dihydrogen and avoid competing hydrogenation reactions. While this is achievable without specialist equipment, it requires a cylinder of hydrogen on hand and is less operationally straightforward than the simple mixing of a catalyst and substrate. Recently, Ahlsten et al. reported the elegant tandem allylic alcohol isomerisation $/ \alpha$-chlorination or $\alpha$-fluorination of a range of substrates by employing typically $0.25-1.0 \mathrm{~mol} \%$ of iridium(III) precursor $\quad\left[\mathrm{IrCl}_{2}\left(\mathrm{Cp}^{*}\right)\right]_{2} \quad\left(\mathrm{Cp}^{*} \quad=\quad 1,2,3,4,5-\right.$ pentamethylcyclopentadienyl) as the catalyst and $\mathrm{N}$ chlorosuccinimide or SelectFluor (1-chloromethyl-4-fluoro-1,4diazoniabicyclo[2.2.2] octane bis(tetrafluoroborate)) as $\mathrm{Cl}$ or $\mathrm{F}$

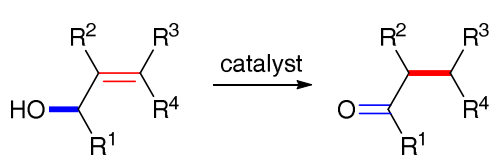

Scheme 1. Isomerisation of allylic alcohols to form ketones. sources, respectively. ${ }^{9,} 10$ This work has since been followed by a related study on the tandem isomerisation-bromination of allylic alcohols, to form $\alpha$-bromoketones. ${ }^{11}$ Notably, the most efficacious catalyst system for this reaction was found to be 1 mol\% $\left[\left\{\operatorname{Ir}\left(\mathrm{Cp}^{*}\right)\right\}_{2}(\mathrm{OH})_{3}\right][\mathrm{OH}] \cdot 11 \mathrm{H}_{2} \mathrm{O}$, which bears hydroxide ligands, in wet acetone at $\mathrm{RT}$ for $0.5-24 \mathrm{~h}$. Alternative catalyst systems $\left[\operatorname{Ir}\left(\mathrm{Cp}^{*}\right)\left(\mathrm{OH}_{2}\right)_{3}\right]\left[\mathrm{SO}_{4}\right]$ and $\left[\mathrm{IrCl}_{2}\left(\mathrm{Cp}^{*}\right)\right]_{2}$ were found to be less active under the same conditions. Palladium hydroxides (in the form of $\mathrm{Pd}(\mathrm{OH})_{2}$ on carbon) have also been used to effect the isomerisation of allylic alcohols. ${ }^{12}$

Recently, we disclosed the synthesis and study of a series of iridium(I) hydroxide complexes of the form $[\operatorname{Ir}(\mathrm{OH})(\mathrm{COD})(\mathrm{NHC})](\mathrm{COD}=1,5$-cyclooctadiene, $\mathrm{NHC}=\mathrm{N}$ heterocyclic carbene) (Scheme 2). ${ }^{13}$ These species are capable of deprotonating acidic $\mathrm{C}-\mathrm{H}, \mathrm{N}-\mathrm{H}$ and $\mathrm{O}-\mathrm{H}$ bonds, activating boronic acids and silanes, or activating $\mathrm{CO}_{2}$ to generate new iridium(I) species. ${ }^{14}$ As the oxidation state of the new complexes remains at +1 , there exists considerable scope for further reaction of these new species. Due to their relative rarity, little is known of their ability or involvement in catalytic reactions.

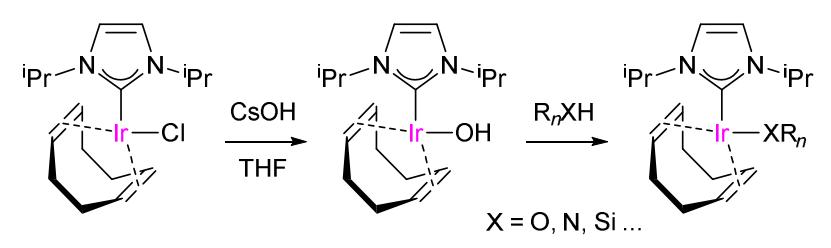

Scheme 2. Iridium(I) hydroxides as building blocks for organometallic chemistry.

The reactivity of the iridium(I) hydroxide was therefore explored in the allylic alcohol isomerisation reaction to investigate the catalytic potential of iridium(I) hydroxide complexes with substrates bearing acidic ( $\mathrm{pKa} \leq c a$. 30) protons. It was reasoned that the initial reaction would be the deprotonation of the substrate, leading to an alkoxide complex; 
the intramolecular nature of subsequent steps might then accelerate the reaction. In particular, it was hoped that the presence of an internal base would preclude the need for additives such as base or hydrogen gas.

Initially, a series of trial reactions were conducted in NMR tubes using model substrate 1-phenylprop-2-en-1-ol and hydroxide complex $\left[\operatorname{Ir}(\mathrm{OH})(\mathrm{COD})\left(\mathrm{I}^{i} \mathrm{Pr}\right)\right](\mathbf{1})\left(\mathrm{I}^{i} \mathrm{Pr}=1,3\right.$-diisopropylimidazol-2ylidene) (Scheme 3). No additives were used; the catalyst and substrate were simply dissolved in dry, oxygen-free toluene- $d_{8}$ and heated in an oil bath. A low catalyst loading of $0.25 \mathrm{~mol} \%$ was employed, in order to be competitive with the state-of-the-art systems. ${ }^{9,} 10$ After mixing the components of the reaction mixture at room temperature, a rapid colour change from bright yellow to orange was observed, in the same manner as was observed in previous deprotonation experiments. ${ }^{13}$ However, no conversion to the product was obtained after $15 \mathrm{~min}$ at room temperature, suggesting that this initial colour change was due to deprotonation of the substrate; unfortunately, at such a low catalyst loading, none of the iridium species are observable by NMR spectroscopy. No conversion was obtained overnight, but the application of heat led to complete conversion. Hydroxide complexes of this type are known to be capable of deprotonating ketones (such as acetone) at the $\alpha$ position, ${ }^{13}$ but pleasingly this side reaction either did not occur, or otherwise did not impede productive catalytic turnover.

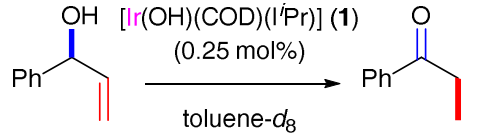

Scheme 3. Trial reactions.

The analogous chloride complex $\left[\operatorname{IrCl}(\mathrm{COD})\left(\mathrm{I}^{i} \mathrm{Pr}\right)\right](2)$, and cationic complexes $\left[\operatorname{Ir}(\mathrm{COD})\left(\mathrm{I}^{i} \mathrm{Pr}^{\mathrm{Me}}\right)(\mathrm{py})\right]\left[\mathrm{PF}_{6}\right]$ (3) and $[\operatorname{Ir}(\mathrm{COD})$ $\left.\left(\mathrm{I}^{i} \mathrm{Pr}^{\mathrm{Me}}\right)_{2}\right]\left[\mathrm{PF}_{6}\right]$ (4) (py = pyridine, $\mathrm{I}^{i} \mathrm{Pr}^{\mathrm{Me}}=1,3$-diisopropyl-4,5dimethylimidazol-2-ylidene) (Figure 1) were also tested under the same conditions $\left(110{ }^{\circ} \mathrm{C}, 16 \mathrm{~h}\right)$ but yielded poorer conversions ( $24 \%, 38 \%$ and $15 \%$, respectively). The hydroxide functionality is clearly important to facilitate catalytic activity in this reaction.
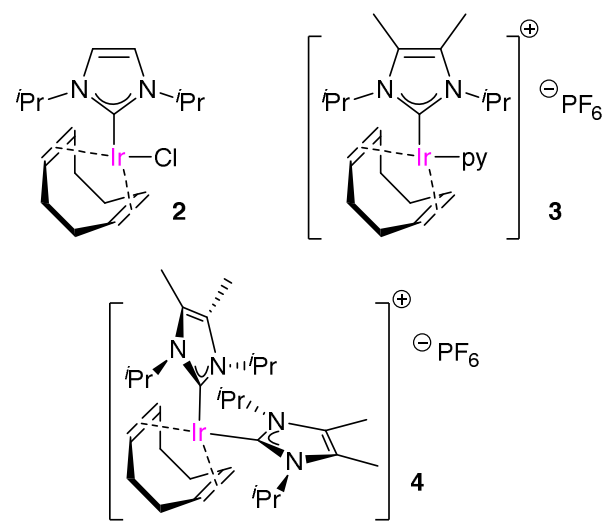

Figure 1. Alternative complexes screened for reactivity.

It was proposed that the hydroxide functionality initially deprotonated the substrate, yielding an iridium(I) alkoxide intermediate that could then isomerise; directly attaching the substrate to the catalyst in this way would promote the reaction by rendering subsequent steps where the catalyst and substrate interact intramolecular in nature. Attempts were made to trap this initial alkoxide species, but with little success. 1:1 mixtures of substrate and hydroxide rarely led to reaction at room temperature, despite the demonstrated ability of the hydroxide complex to react with a range of acidic protons. ${ }^{13}$ The application of heat led to the allylic alcohol isomerisation reaction taking place. The reaction of the iridium(I) hydroxide complex with 1 equiv. cyclohex-2-en-1-ol at room temperature led to a 1:1 mixture of iridium(I) hydroxide and an unknown species, as determined by the presence of ${ }^{1} \mathrm{H}$ NMR signals corresponding to the $\mathrm{I}^{i} \mathrm{Pr} \mathrm{NHC}$ in a different environment. No signals corresponding to iridium hydride species were observed on the ${ }^{1} \mathrm{H}$ NMR spectrum. Unfortunately, this new species could not be isolated, although the addition of degassed water led to isolation of only the $\operatorname{Ir}\left(I^{i} \operatorname{Pr}\right)$ hydroxide . Our hypothesis at this stage is that the deprotonation, while feasible, is slow and disfavoured, and that heating is necessary to overcome the subsequent barriers in the catalytic cycle.

Having established the necessary conditions, the scope and limitations of the reaction were briefly explored (Figure 2). Notably, most reactions proceed with $0.25 \mathrm{~mol} \%$ iridium, and turnover numbers (TON) of $c a .700$ are achievable. Primary alcohols can be converted to aldehydes, but with low TON ( $c a .20)$; these substrates are known to be particularly challenging in allylic alcohol isomerisation reactions. ${ }^{2}$ Steric bulk is tolerated at the $\beta$-position, but $\alpha$-substitution impedes the reaction, presumably due to impeding the removal of the proton that must be removed to generate the carbonyl motif. Conjugated substrates were successfully isomerised, although in each case the ketone is in conjugation with an aromatic system in the product. Alkyl and aryl-bearing substrates both undergo reaction, although cyclohex-2-en-1-ol reacted more slowly than oct-1-ene-3ol.

However, the use of high temperatures for prolonged reaction times is not necessarily economical, so the use of microwave heating was explored instead. While there has been much discussion regarding the efficiency of microwave heating versus conventional heating, the consensus appears to be that one method is not automatically superior to the other in terms of energy efficiency, and that the most efficient method will depend significantly on the apparatus and chemistry utilised. ${ }^{15}$ However, a reduction in energy consumption is likely to be achieved if the use of microwave heating permits a significant reduction in reaction time; in one case study by Kappe, a reduction in the reaction time from $c a .3-6 \mathrm{~h}$ to $<5 \mathrm{~min}$ allowed a significant reduction in energy consumption, even when a relatively non-polar solvent was used (toluene). ${ }^{16}$ An increase in reaction temperature, above the boiling point of the solvent, can allow reactions to be completed in much shorter times. A move to microwave heating was therefore prompted primarily by a desire to render the procedure rapid and convenient. Initial optimisation, in which various solvents, temperatures and catalyst loadings were screened, highlighted the use of $0.1 \mathrm{~mol} \%$ of catalyst in either THF $(\varepsilon=7.47)^{17}$ or toluene $(\varepsilon=2.43)^{17}$ at $150{ }^{\circ} \mathrm{C}$ for $0.5-1.0 \mathrm{~h}$ to be the optimum conditions (Table 1). Notably, this represents a 2.5 -fold reduction in catalyst loading as well as a remarkable reduction in 


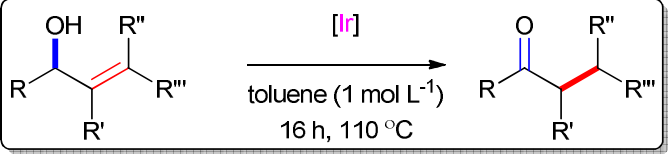<smiles>CCC(=O)c1ccccc1</smiles>

$0.25 \mathrm{~mol} \%>95 \%$

$0.125 \mathrm{~mol} \% \quad 87 \%$

$0.0625 \mathrm{~mol} \% \quad 48 \%$<smiles>O=C(CCc1ccccc1)c1ccccc1</smiles>

$0.25 \mathrm{~mol} \%>95 \%$<smiles>O=CCCc1ccccc1</smiles>

$0.25 \mathrm{~mol} \% \quad 7 \%$ $1 \mathrm{~mol} \%$<smiles>CC(C)C(=O)c1ccccc1</smiles>
$\begin{array}{lrr}0.25 \mathrm{~mol} \% & <5 \% & 0.25 \mathrm{~mol} \% \\ 1 \mathrm{~mol} \% & 89 \%\end{array}$<smiles>O=C(CCc1ccccc1)c1ccc(F)cc1</smiles><smiles>CC(C)CC(=O)c1ccccc1</smiles><smiles>O=C1CCCCC1</smiles>

$0.25 \mathrm{~mol} \%>95 \%$

$0.25 \mathrm{~mol} \%>95 \%$ $0.25 \mathrm{~mol} \% \quad 88 \% *$

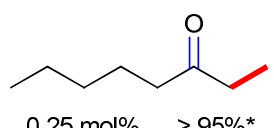

Conversion determined by integration of the ${ }^{1} \mathrm{H}$ NMR spectrum

( ${ }^{*}$ Reactions conducted in toluene- $\left.d_{8}\right)$

Figure $\mathbf{2}$ Scope and limitations of the thermal reaction.

Table 1. Screening microwave conditions for the iridium-catalysed isomerisation reaction of 1-phenylprop-2-en-1-ol. ${ }^{\text {a }}$

\begin{tabular}{ccccc}
\hline Entry & {$[\mathbf{I r}] / \mathbf{m o l} \%$} & Solvent & $\mathbf{T}$ & Conv. $^{\text {b }}$ \\
\hline 1 & 0.25 & MeCN & $150{ }^{\circ} \mathrm{C}$ & $35 \%$ \\
2 & 0.25 & DMF & $150{ }^{\circ} \mathrm{C}$ & $86 \%$ \\
3 & 0.25 & Toluene & $150{ }^{\circ} \mathrm{C}$ & $>95 \%$ \\
4 & 0.25 & THF & $150{ }^{\circ} \mathrm{C}$ & $>95 \%$ \\
5 & 0.1 & THF & $150{ }^{\circ} \mathrm{C}$ & $>95 \%$ \\
6 & 0.1 & Toluene & $140{ }^{\circ} \mathrm{C}$ & $70 \%$ \\
$7^{\text {c }}$ & 0.1 & Toluene & $140{ }^{\circ} \mathrm{C}$ & $>95 \%$ \\
6 & 0.05 & THF & $150{ }^{\circ} \mathrm{C}$ & $65 \%$ \\
7 & 0.1 & THF & $130{ }^{\circ} \mathrm{C}$ & $62 \%$ \\
$8^{d}$ & 0.1 & THF & $150{ }^{\circ} \mathrm{C}$ & $>95 \%$ \\
\hline
\end{tabular}

a $1 \mathrm{mmol}$ substrate in $1 \mathrm{~mL}$ solvent, plus indicated loading of $\left[\operatorname{Ir}(\mathrm{OH})(\mathrm{COD})\left(\mathrm{I}^{i} \mathrm{Pr}\right)\right]$, heated to $\mathrm{T}$ for $30 \mathrm{~min}$ by microwave irradiation. ${ }^{\mathrm{b}}$ Determined by ${ }^{1} \mathrm{H}$ NMR integration. ${ }^{\mathrm{c}} 1 \mathrm{~h} .{ }^{\mathrm{d}}\left[\mathrm{IrCl}(\mathrm{COD})\left(\mathrm{I}^{i} \mathrm{Pr}\right)\right]$ (2) plus 10 $\mathrm{mol} \% \mathrm{KOH}$.

reaction time compared to the thermal conditions explored previously.

Equivalent results were achieved when $0.1 \mathrm{~mol} \%$ of $\left[\mathrm{IrCl}(\mathrm{COD})\left(\mathrm{I}^{i} \mathrm{Pr}\right)\right]$ (2) was used with $10 \mathrm{~mol} \% \mathrm{KOH}$; while this requires the use of base, it precludes the need to synthesise and isolate the oxygen-sensitive iridium(I) hydroxide complex. We hypothesise that either the hydroxide is formed in situ, or that the substrate is deprotonated and the potassium alkoxide complex reacts with the iridium chloride species. Iridium complexes of this motif are generally very easy to prepare, ${ }^{13,18,19}$ and tend to be air-stable, which may widen the appeal and accessibility of this protocol.

With these optimised conditions in hand, the scope and limitations of the microwave-irradiated reaction were explored using toluene as solvent. The yields reported in Figure $\mathbf{3}$ are isolated yields after purification of the products by silica gel chromatography. All substrates can be converted in short reaction times, in very good to excellent isolated yields. This therefore represents a useful, general methodology for carrying out this isomerisation reaction in the absence of base or additives.<smiles>CCC(=O)c1ccccc1</smiles>

$90 \%$<smiles>CCC(=O)CCCCCC(=O)OCc1ccc(C(=O)OCc2ccccc2)cc1</smiles><smiles>O=C(CCc1ccccc1)c1ccccc1</smiles>

$91 \%$

Figure 3 Scope and limitations of allylic alcohol isomerisation under microwave irradiation (isolated yields after purification by silica gel chromatography).

\section{Conclusions}

It has been shown that iridium(I) hydroxides are capable of catalysing the isomerisation of allylic alcohols to form ketones. Notably, this is the first deployment of iridium(I) hydroxide in catalysis. A range of compounds was successfully transformed to ketones using low (typically $0.25 \mathrm{~mol} \%$ ) loadings of iridium. Two protocols were provided: one using conventional heating, and one using microwave heating to effect short and convenient reaction times. Notably, neither protocol requires the use of hydrogen or the presence of base, rendering it highly practical and compatible with sensitive functional groups, although the iridium chloride complex plus an alkoxide base can be used instead of the iridium(I) hydroxide species.

Further work continues in our laboratories to probe mechanistic aspects of this transformation, with the aim of using the hydroxide species to prepare and study the postulated intermediate alkoxide.

We thank the EPSRC, the ERC (Advanced Investigator Award 'FUNCAT' to SPN), and Sasol (stipend to BJT) for funding. SPN is a Royal Society Wolfson Merit Award holder. 


\section{Experimental section}

General. All manipulations were performed insight an argonfilled glovebox or using standard Schlenk techniques under an argon atmosphere unless otherwise stated. $[\operatorname{IrCl}(\mathrm{COD})]_{2}$ and $[\mathrm{RhCl}(\mathrm{COD})]_{2}$ were obtained from Umicore AG; complexes 1 and 2 were prepared using literature methods. ${ }^{13}$ NMR data were obtained using Bruker spectrometers at 300,400 or $500 \mathrm{MHz}$ $\left({ }^{1} \mathrm{H}\right.$ observe frequency); all chemical shifts are given in ppm and coupling constants in $\mathrm{Hz}$, referenced to residual proton signals $\left({ }^{1} \mathrm{H}\right)$ or solvent signals $\left({ }^{13} \mathrm{C}\left\{{ }^{1} \mathrm{H}\right\}\right) \cdot{ }^{20}$ Elemental analyses were performed at London Metropolitan University.

[Ir(COD)(I'PrMe)(py)][PF $]$ (3). Analogous to the reported procedure, ${ }^{21}$ in the glovebox, toluene $(1 \mathrm{~mL})$ was added to $\left[(\mathrm{py})_{2} \operatorname{Ir}(\mathrm{COD})\right]\left[\mathrm{PF}_{6}\right](50.0 \mathrm{mg}, 0.083 \mathrm{mmol})$ and $\mathrm{I}^{i} \mathrm{PrMe}(14.9$ $\mathrm{mg}, 0.083 \mathrm{mmol}, 1.00$ equiv.). The suspension was stirred at room temperature for $48 \mathrm{~h}$, during which time a yellow precipitate formed. The solid was filtered off and washed with cold pentane $(3 \times 0.5 \mathrm{~mL})$ and dried in vacuo. Yield: $47.2 \mathrm{mg}$ $(0.067 \mathrm{mmol}, 81 \%)$ of a yellow powder. ${ }^{1} \mathbf{H} \mathbf{~ N M R}\left(\mathrm{CD}_{2} \mathrm{Cl}_{2}\right): \delta$ $8.65-8.56(2 \mathrm{H}, \mathrm{m}, \mathrm{ArH}), 7.82\left(\mathrm{tt}, 1 \mathrm{H},{ }^{3} J_{H H}=7.8,1.6, \mathrm{ArH}\right)$, $7.54-7.46(\mathrm{~m}, 2 \mathrm{H}, \mathrm{ArH}), 5.90\left(\mathrm{sept}, 2 \mathrm{H},{ }^{3} J_{\mathrm{HH}}=7.1\right.$, $\mathrm{NCHMe}$ ), 3.93 - 3.81 (m, 2H, COD), 3.74 - $3.64(\mathrm{~m}, 2 \mathrm{H}$, COD), 2.42-2.29 (m, 4H, COD), 2.14 (s, 6H, $\left.(\mathrm{N} M e)_{2}\right), 1.99$ 1.84 (m, 4H, COD), 1.65 (d, $6 \mathrm{H}, \mathrm{J}=7.1, \mathrm{NCHMe}$ ), 1.40 (d, $6 \mathrm{H}, \mathrm{J}=7.1, \mathrm{NCHMe} 2) .{ }^{13} \mathbf{C}\left\{{ }^{1} \mathbf{H}\right\} \mathbf{N M R}\left(\mathrm{CD}_{2} \mathrm{Cl}_{2}\right): \delta 172.5$ (Ir-C), 150.6 (py), 138.7 (py), 127.2 (py), $126.5\left(\mathrm{~N}\left(\mathrm{CCH}_{3}\right)_{2} \mathrm{~N}\right), 82.5$ (COD CH), $64.4(\mathrm{COD} \mathrm{CH}), 54.3\left(\mathrm{CH}\left(\mathrm{CH}_{3}\right)_{2}\right), 32.8$ (COD $\left.\mathrm{CH}_{2}\right), 30.3\left(\mathrm{COD} \mathrm{CH}_{2}\right), 22.8\left(\mathrm{CH}\left(\mathrm{CH}_{3}\right)_{2}\right), 22.6\left(\mathrm{CH}\left(\mathrm{CH}_{3}\right)_{2}\right)$, $10.4\left(\mathrm{~N}\left(\mathrm{CCH}_{3}\right)_{2} \mathrm{~N} .{ }^{19} \mathbf{F}\left\{{ }^{1} \mathbf{H}\right\}\right.$ NMR $\left(\mathrm{CD}_{2} \mathrm{Cl}_{2}\right): \delta-73.9\left(\mathrm{~d},{ }^{1} J_{\mathrm{PF}}=\right.$ 710.2). ${ }^{31} \mathbf{P}\left\{{ }^{1} \mathbf{H}\right\} \mathbf{N M R}\left(\mathrm{CD}_{2} \mathrm{Cl}_{2}\right): \delta-144.5$ (sept., ${ }^{1} J_{\mathrm{FP}}=710.2$ ). Anal. Calcd for $\mathrm{C}_{24} \mathrm{H}_{37} \mathrm{~N}_{3} \mathrm{~F}_{6} \mathrm{PIr}$ : C, 40.90; H, 5.29; N, 5.96. Found: C, 40.89; H, 5.25; N, 6.06.

$\left[\operatorname{Ir}(\mathbf{C O D})\left(\mathbf{I}^{i} \mathbf{P r M e}\right)(\mathbf{p y})\right]\left[\mathbf{P F}_{6}\right](\mathbf{4})$. In the glovebox, toluene (1 $\mathrm{mL})$ was added to $\left[(\mathrm{py})_{2} \operatorname{Ir}(\mathrm{COD})\right]\left[\mathrm{PF}_{6}\right](49.8 \mathrm{mg}, 0.083 \mathrm{mmol})$ and $\mathrm{I}^{i} \mathrm{PrMe}$ (29.9 mg, $0.166 \mathrm{mmol}, 2.01$ equiv.). The suspension was stirred at room temperature for $48 \mathrm{~h}$, during which time a bright orange precipitate formed. The solid was filtered off and washed with cold pentane $(3 \times 0.5 \mathrm{~mL})$ and dried under high vacuum. Yield: $52.3 \mathrm{mg}(0.065 \mathrm{mmol}, 79 \%)$ of a bright orange powder. ${ }^{1} \mathbf{H}$ NMR $\left(\mathrm{CD}_{2} \mathrm{Cl}_{2}\right): \delta 5.35$ (sept, $4 \mathrm{H},{ }^{3} J_{\mathrm{HH}}=7.0$, $\left.\mathrm{CH}\left(\mathrm{CH}_{3}\right)_{2}\right), 3.93-3.81(\mathrm{~m}, 4 \mathrm{H}, \mathrm{COD}), 2.22(\mathrm{~s}, 12 \mathrm{H}$, $\left.\mathrm{N}\left(\mathrm{CH}_{3}\right)_{2} \mathrm{~N}\right), 2.20-2.13(\mathrm{~m}, 4 \mathrm{H}, \mathrm{COD}), 1.80-1.71(\mathrm{~m}, 4 \mathrm{H}$, COD $), 1.57\left(\mathrm{~d}, 12 \mathrm{H},{ }^{3} J_{H H}=7.0, \mathrm{CH}\left(\mathrm{CH}_{3}\right)_{2}\right), 1.24\left(\mathrm{~d}, 12 \mathrm{H},{ }^{3} J_{H H}\right.$ $\left.=7.0, \mathrm{CH}\left(\mathrm{CH}_{3}\right)_{2}\right) \cdot{ }^{13} \mathbf{C}\left\{{ }^{1} \mathrm{H}\right\}$ NMR $\left(\mathrm{CD}_{2} \mathrm{Cl}_{2}\right): \delta 175.0$ (Ir-C), $126.8\left(\mathrm{~N}\left(\mathrm{CCH}_{3}\right)_{2} \mathrm{~N}\right), 73.4(\mathrm{COD} \mathrm{CH}), 54.2\left(\mathrm{CH}\left(\mathrm{CH}_{3}\right)_{2}\right), 32.4$

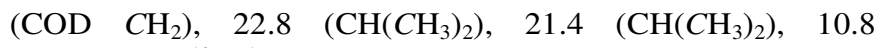
$\left(\mathrm{N}\left(\mathrm{CCH}_{3}\right)_{2}\right) .{ }^{19} \mathbf{F}\left\{{ }^{1} \mathbf{H}\right\}$ NMR $\left(\mathrm{CD}_{2} \mathrm{Cl}_{2}\right): \delta-74.0\left(\mathrm{~d},{ }^{1} J_{\mathrm{PF}}=709.9\right)$. ${ }^{31} \mathbf{P}\left\{{ }^{1} \mathbf{H}\right\}$ NMR $\left(\mathrm{CD}_{2} \mathrm{Cl}_{2}\right): \delta-144.5$ (sept., $\left.{ }^{1} J_{\mathrm{FP}}=709.9\right)$. The methine ${ }^{13} \mathrm{C}$ signal was located using $\left[{ }^{1} \mathrm{H},{ }^{13} \mathrm{C}\right] \mathrm{HSQC}$ analysis. Anal. Calcd for $\mathrm{C}_{29} \mathrm{H}_{52} \mathrm{~N}_{4} \mathrm{~F}_{6} \mathrm{PIr}$ : C, 44.71; H, 6.50; N, 6.95. Found: C, 44.76; H, 6.36; N, 6.87.

General procedure for the isomerisation of allylic alcohols under thermal conditions. In the glovebox, a vial containing a stir bar was charged with the substrate $(1.0 \mathrm{mmol})$ and $\left[\operatorname{Ir}(\mathrm{OH})(\mathrm{COD})\left(\mathrm{I}^{i} \mathrm{Pr}\right)\right](0.25 \mathrm{~mol} \%)$ in toluene $(1 \mathrm{~mL})$. The reaction mixture was removed from the glovebox and stirred for $16 \mathrm{~h}$ at $110{ }^{\circ} \mathrm{C}$. Following this, the solvent was removed in vacuo and ${ }^{1} \mathrm{H} \mathrm{NMR}$ analysis was conducted in $\mathrm{CDCl}_{3}$ to determine conversion relative to the starting material. Where the products are volatile, the reaction was carried out in toluene- $d_{8}$ and analysed without work-up. ${ }^{1} \mathrm{H}$ NMR of all products were compared to literature reports. ${ }^{4}$

General procedure for the isomerisation of allylic alcohols under microwave irradiation. In the glovebox, a $10 \mathrm{~mL}$ microwave vial (fitted with septum cap) containing a stir bar was charged with the substrate $(1.0 \mathrm{mmol})$ and $\left[\operatorname{Ir}(\mathrm{COD})\left(\mathrm{I}^{i} \mathrm{Pr}\right)(\mathrm{OH})\right](0.1 \mathrm{~mol} \%)$ in toluene $(1 \mathrm{~mL})$. The reaction mixture was removed from the glovebox and irradiated in the microwave at $140{ }^{\circ} \mathrm{C}, 150 \mathrm{~W}$ for $1 \mathrm{~h}$. The resultant mixture was chromatographed (flash chromatography, elution with pentane-ethyl acetate [40:1]) to afford the product.

\section{Acknowledgements}

We thank Simone Manzini for synthesis of some of the substrates, Dr Catherine S. J. Cazin for use of the microwave, and Melanja Smith and Dr Tomas Lebl for assistance with NMR spectroscopy facilities. We thank Umicore AG for a gift of materials. THF and toluene were obtained from a solvent purification system and stored under argon in the glovebox. Acetonitrile and DMF were purchased as anhydrous under argon and stored in the glovebox. Deuterated solvents for the analysis of metal complexes were dried on calcium hydride and distilled before use and stored under argon; deuterated solvents for the analysis of starting materials and products were used as supplied.

\section{Notes and references}

${ }^{a}$ EaStCHEM School of Chemistry, University of St Andrews, North Haugh, Fife, KY16 9ST, UK. Email: snolan@st-andrews.ac.uk.

${ }^{b}$ Current address: WestCHEM Department of Pure and Applied Chemistry, University of Strathclyde, 295 Cathedral Street, Glasgow, G1 $1 \mathrm{XL}, \mathrm{UK}$.

$\dagger$ Electronic Supplementary Information (ESI) available: Synthesis and characterisation of $\left[\operatorname{Ir}(\mathrm{COD})\left(\mathrm{I}^{i} \mathrm{Pr}^{\mathrm{Me}}\right)(\mathrm{py})\right]\left[\mathrm{PF}_{6}\right]$ and $\left[\operatorname{Ir}(\mathrm{COD})\left(\mathrm{I}^{i} \mathrm{Pr}^{\mathrm{Me}}\right)_{2}\right]$ $\left[\mathrm{PF}_{6}\right]$, and NMR spectra of isolated reaction products. See DOI: $10.1039 / \mathrm{c} 000000 \mathrm{x} /$

1. R. C. van der Drift, E. Bouwman and E. Drent, J. Organomet. Chem., 2002, 650, 1-24.

2. R. Uma, C. Crévisy and R. Grée, Chem. Rev., 2002, 103, $27-52$.

3. N. Ahlsten, A. Bartoszewicz and B. Martin-Matute, Dalton Trans., 2012, 41, 1660-1670.

4. S. Manzini, A. Poater, D. J. Nelson, L. Cavallo and S. P. Nolan, Chem. Sci., 2014, 5, 180-188.

5. L. Mantilli, D. Gerard, S. Torche, C. Besnard and C. Mazet, Angew. Chem. Int. Ed., 2009, 48, 5143-5147.

6. L. Mantilli and C. Mazet, Tetrahedron Lett., 2009, 50, 4141-4144.

7. L. Mantilli, D. Gerard, S. Torche, C. Besnard and C. Mazet, Pure Appl. Chem., 2010, 82, 1461-1469.

8. L. Mantilli, D. Gérard, C. Besnard and C. Mazet, Eur. J. Inorg. Chem., 2012, 2012, 3320-3330.

9. N. Ahlsten and B. Martin-Matute, Chem. Commun., 2011, 47, 8331-8333.

10. N. Ahlsten, A. Bermejo Gómez and B. Martín-Matute, Angew. Chem. Int. Ed., 2013, 52, 6273-6276. 
11. A. B. Gómez, E. Erbing, M. Batuecas, A. Vázquez-Romero and B. Martín-Matute, Chem. Eur. J., 2014, n/a-n/a.

12. G. Sabitha, S. Nayak, M. Bhikshapathi and J. S. Yadav, Org. Lett., 2010, 13, 382-385.

13. B. J. Truscott, D. J. Nelson, C. Lujan, A. M. Z. Slawin and S. P. Nolan, Chem. Eur. J., 2013, 19, 7904-7916.

14. B. J. Truscott, D. J. Nelson, A. M. Z. Slawin and S. P. Nolan, Chem. Commun., 2014, 50, 286-288.

15. J. D. Moseley and C. O. Kappe, Green Chem., 2011, 13, 794-806.

16. T. Razzaq and C. O. Kappe, ChemSusChem, 2008, 1, 123-132.

17. J. L. M. Abboud and R. Notari, Pure Appl. Chem., 1999, 71, 645718.

18. S. Leuthäußer, D. Schwarz and H. Plenio, Chem. Eur. J., 2007, 13, 7195-7203.

19. R. A. Kelly III, H. Clavier, S. Giudice, N. M. Scott, E. D. Stevens, J. Bordner, I. Samardjiev, C. D. Hoff, L. Cavallo and S. P. Nolan, Organometallics, 2007, 27, 202-210.

20. G. R. Fulmer, A. J. M. Miller, N. H. Sherden, H. E. Gottlieb, A. Nudelman, B. M. Stoltz, J. E. Bercaw and K. I. Goldberg, Organometallics, 2010, 29, 2176-2179.

21. A. C. Hillier, H. M. Lee, E. D. Stevens and S. P. Nolan, Organometallics, 2001, 20, 4246-4252.

\section{Graphical TOC}

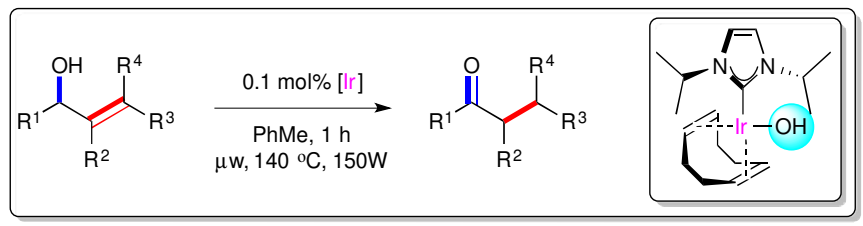

